\title{
Educational Travel Programs, Sustainability, and the Environment
}

\author{
Brack W. Hale
}

Citation: Hale, B.W. Educational

Travel Programs, Sustainability, and the Environment. Sustainability 2022, 14, 2454. https://doi.org/10.3390/ su14042454

Received: 8 February 2022

Accepted: 12 February 2022

Published: 21 February 2022

Publisher's Note: MDPI stays neutral with regard to jurisdictional claims in published maps and institutional affiliations.

Copyright: (C) 2022 by the author. Licensee MDPI, Basel, Switzerland This article is an open access article distributed under the terms and conditions of the Creative Commons Attribution (CC BY) license (https:// creativecommons.org/licenses/by/ $4.0 /)$.
Environmental Science and Studies, Franklin University Switzerland, 6924 Sorengo, Switzerland; bhale@fus.edu

\section{Introduction}

This Special Issue seeks to contribute to the growing body of literature that considers and examines the multiple ways that educational travel programs (ETPs), such as study abroad, service learning, and educational exchange programs, educate students about environmental and sustainability issues, as well as how the programs themselves interact with these same issues. ETPs have been an important tool to provide students with a cross-cultural education for years. They have been recognized for the quality learning experiences that such settings can allow, particularly when organized around the principles of experiential education. The literature hitherto has not only provided evidence of the general effectiveness of the educational experience but has also assessed its inherent ability to enhance specifically environmental and sustainability education for the participants. At the same time, these programs have been critiqued for their likely impacts on destination cultures, environments, and societies.

The contributions in this Special Issue focus on ETPs in higher education in Europe [1,2] and the United States [3-7]. They examine both immediate [1,3-5] and longterm [7] educational gains for the students participating in ETPs in general and those that focus on sustainability or the environment. They also consider the impacts that the host community might experience from these programs [2,6]. Many of the contributions also consider the impacts of the COVID-19 pandemic, which was at its height during the production of this issue. The travel restrictions the pandemic triggered put most programs on hold and provided stakeholders an opportunity to reflect on role and impacts of ETPs. In general, these articles strengthen our understanding of ETPs and provide current and future programs ways to design curricula that enhance learning about sustainability while improving their own sustainability and reducing impacts on host destinations

\section{Overview of Contributions}

Several contributions focus specifically on the ability and success of ETPs to teach students within the context of sustainability. The research by Tarrant, Schweinsberg, Landon, Wearing, McDonald, and Rubin [4] looks at how sustainability education, both on campus and within an ETP, can promote student engagement, an important aspect of general student learning. The authors examined how improvements in student scores on certain components of the National Survey on Student Engagement related to participation in sustainability-related courses on-campus and in short-term ETPs. They found that both studying sustainability and studying in short-term ETP yielded significantly greater benefits for student engagement than for students not studying sustainability or participating in an ETP. As such, the study provides more evidence for the effective learning environment delivered by ETPs.

De La Torre, Perez-Encinas, and Gomez-Mediavilla [1] provide a European perspective on ETPs, examining how the Erasmus program can help contribute to sustainability education by contributing to the UN Sustainable Development Goals (SDGs) through the development of relevant knowledge, skills, and attitudes (KSA). The researchers identified the KSAs associated with educational travel and mapped how they connected to individual SDGs (NB: the research focused on the general Erasmus program and not individual 
program contents). Using focus groups of students leaving for and returning from Erasmus exchanges, they found that the programs support the development of many KSAs related to the SDGs. The authors also identify ways that institutions could expand and improve these gains.

The contribution from Ling, Landon, Tarrant, and Rubin [3] examines the impact coursework in sustainability, taken on campus or as part of an educational travel program, has on participants' sustainability literacy (economic, environmental, and social). Using an assessment tool developed from other existing surveys, the authors found that sustainability courses embedded within an ETP provided the largest, most significant gains in sustainability literacy compared to on-campus courses (both ones that dealt with sustainability themes or other non-sustainability related courses) and other ETPs that did not deal explicitly with a sustainability-related theme. The authors propose that the gains likely relate to multiple factors, including the experiential nature of the programs and the diversity of teaching approaches commonly used in ETPs. Another interesting finding was that the gains for students in on-campus sustainability courses was not significantly greater than ETPs that did not examine sustainability, supporting previous studies that found that the educational travel experience alone can contribute to sustainability literacy for student participants.

The contribution by McLaughlin [5] provides an excellent example of what an intentionally designed experiential ETP can look like. The article examines the success she and her colleagues have had at integrating a course-based undergraduate research experience (CURE) into an experiential ETP, which they had developed focusing on humans and nature. The model for their ETP includes pre- and post-travel experiences that frame the field experience. McLaughlin highlights the importance of the local partnerships they cultivate in each destination, which allow students to engage in real-world research. Program assessments show that students demonstrate solid learning outcomes in conservation biology and environmental science, as well as global citizenship.

Whereas the above studies examined student gains immediately following participation in an ETP, Zhang and Gibson [7] investigate longer-term impacts from such participation and focus specifically on participation in ETPs that examined sustainability. They interviewed program participants in the first decade after ETP participation to find out how attitudes and values had changed. Like many of the other studies, their focus was on participants in short-term ETPs. The results indicated that participants generally maintained a "sustainability mindset" after graduating. Some participants reported that the experience sometimes provided insights into new career paths, while others mentioned that it affected the way they now travel. The authors also found that these changes came through behavioral, cognitive, and emotional aspects of the program and its design.

The last two articles in this issue examine how ETPs affect their host destinations. The article by Gregory, Schroeder, and Wood [6] encourages a radical rethinking of how institutions engage in international service learning as part of ETPs. They stress that many existing programs reinforce outdated stereotypes of countries in the Global South and fail to understand and educate their participants about issues of power and privilege related to service. Furthermore, the programs often result in "bad service" that does more harm than good to the host community. Students are frequently ill-prepared and lack the skills necessary for the service projects in which they participate. The authors call for major changes in these programs that include eliminating the idea of service and instead engaging in projects that develop out of strong relationships between the sending institution and the community. Such projects should also allow reciprocal exchanges between students and the community, rather than a one-sided approach that frames students as experts. They also argue that destinations at high risk for harm or negative impacts must be avoided.

The article by Hale [2] also posits that benefits of ETPs for students and sending institutions should not come at costs to the host community or its environment. It uses two case studies to show how important destination choice and program timing are for creating more sustainable programs. It also provides examples of how an ETP can structure itself to 
promote both student learning and positive benefits for the local community: specifically, the role that citizen science programs and research service-learning approaches can play. The article highlights the need for strong relationships between the ETP and the local partners that permit the co-creation of the curriculum and program. Lastly, it examined how the COVID-19 pandemic impacted the role of ETPs in the host communities: It found that there were both negative impacts (e.g., loss of cultural exchanges) and positive impacts (e.g., increased (local) participation in citizen science programs).

\section{Future Directions}

There remain much we need to learn about the interface between ETPs and sustainability. The current articles focus on programs stemming from institutions in Europe and the U.S. and programs at institutions of higher education. Perspectives from other regions of the world and from other levels of education will be important to help elucidate the larger realm of ETPs, their benefits for students, and their interactions with and effects on the host destinations. As several articles also mention, we need to understand better what specific aspects of the ETP experience are enhancing the learning outcomes. As the world moves forward into a future where educational travel programs are once more able to take place, the sponsoring institutions will hopefully do so with more intentionality in their design and execution. The environmental and social challenges of the present and future are significant, so it is more important than ever that ETPs offer powerful programs with lifelong learning while simultaneously interacting respectfully with the people and environments in their destinations.

Funding: This research received no external funding.

Conflicts of Interest: The author/guest editor is an author of one of the contributions and leads educational travel programs through his home institution.

\section{References}

1. De La Torre, E.M.; Perez-Encinas, A.; Gomez-Mediavilla, G. Fostering Sustainability through Mobility Knowledge, Skills, and Attitudes. Sustainability 2022, 14, 1349. [CrossRef]

2. Hale, B.W. Educating for the Environment: The Role of the Host Destination in Education Travel Programs. Sustainability 2021, 13, 8351. [CrossRef]

3. Ling, S.; Landon, A.; Tarrant, M.; Rubin, D. The Influence of Instructional Delivery Modality on Sustainability Literacy. Sustainability 2021, 13, 10274. [CrossRef]

4. Tarrant, M.; Schweinsberg, S.; Landon, A.; Wearing, S.L.; McDonald, M.; Rubin, D. Exploring Student Engagement in Sustainability Education and Study Abroad. Sustainability 2021, 13, 12658. [CrossRef]

5. McLaughlin, J.S. Teaching Environmental Sustainability while Transforming Study Abroad. Sustainability 2020, 13, 50. [CrossRef]

6. Gregory, L.; Schroeder, K.; Wood, C. A Paradigm Shift in International Service-Learning: The Imperative for Reciprocal Learning. Sustainability 2021, 13, 4473. [CrossRef]

7. Zhang, H.; Gibson, H.J. Long-Term Impact of Study Abroad on Sustainability-Related Attitudes and Behaviors. Sustainability 2021, 13, 1953. [CrossRef] 